\title{
PENINGKATAN MUTU PESANTREN MELALUI PENERAPAN MANAJEMEN SUMBER DAYA MANUSIA
}

\author{
Mashuri Toha, Parisi \\ Institut Dirosat Islamiyah Al-Amien Prenduan \\ Email: huriemo@gmail.com, fariez.gastilo@gmail.com
}

\begin{abstract}
Abstrak: Keberadaan pesantren di Indonesia sangat penting. Hal ini dikarenakan pesantren sudah memberikan kontribusi penting dalam upaya mendidik dan mencerdaskan masyarakat Indonesia. Akan tetapi, pesantren perlu melakukan komunikasi dengan perkembangan zaman agar bisa menjadi lembaga pendidikan yang bisa melahirkan lulusan yang bisa bersaing di tengahtengah masyarakat. Ini perlu dilakukan meskipun pesantren memiliki keunikan tersendiri, baik dari cara dan pandangan hidup yang dianut, tata nilai yang diikuti, dan hierarki kekuasaan intern yang ditaati oleh penghuninya, menjadikan pesantren sebagai sub kultural di Indonesia. Penelitian kualitatif ini berusaha mengungkap bagaimana upaya Pondok Pesantren Kembang Kuning Lancar Larangan Pamekasan Jawa Timur dalam meningkatkan kualitas dan mutu pendidikan dan manajemennya dengan memaksimalkan manajemen sumberdaya manusia. Pesantren ini sudah berupaya untuk perencanaan, pengorganisasian, pengarahan dan pengendalian guru dan tenaga pendidikan yang dimilikinya dengan baik untuk meningkatkan kualitas dan mutu pendidikan dan manajemennya.
\end{abstract}

Kata Kunci: Mutu dan Manajemen Sumber Daya Manusia, Pesantren

Abstract: The existence of pesantren in Indonesia is very important. This is because pesantren have made an important contribution in educating the Indonesian people. However, pesantren need to communicate with the times so that they can become educational institutions that can produce graduates who 
can compete in the midst of society. This needs to be done even though pesantren has its own uniqueness, both from the way and view of life adopted, the values that are followed, and the internal hierarchy of power that is adhered to by its inhabitants, making pesantren a sub-culture in Indonesia. This qualitative research seeks to reveal how the efforts of the Kembang Kuning Islamic Boarding School in Pamekasan, East Java, in improving the quality and quality of education and its management by maximizing human resource management. This pesantren has made efforts to plan, organize, direct and control its teachers and education personnel properly to improve the quality and quality of education and its management.

Keyword: Pesantren, Quality and Human Resource Management

\section{PENDAHULUAN}

Pesantren merupakan pendidikan asli Indonesia. Sejak berabad-abad memberikan kontribusi dalam mendidik masyarakat Indonesia. Selain itu, pesantren memiliki keunikan tersendiri, baik dari cara dan pandangan hidup yang dianut, tata nilai yang diikuti, dan hierarki kekuasaan intern yang ditaati oleh penghuninya, menjadikan pesantren sebagai sub kultural di Indonesia. ${ }^{1}$

Seiring dengan perubahan ruang dan waktu sistem pendidikan pesantren mengalami pergeseran-pergeseran baik dari kelembagaan pesantren, metodologi sampai pola hidup di pesantren mengalami perubahan. Namun demikian lembaga pendidikan ini masih tetap bertahan karena masih menyesuaikan diri dengan perubahan-perubahan yang terjadi. Upaya-upaya pembaharuan pesantren telah banyak dari waktu ke waktu untuk

\footnotetext{
1 Moh Hamzah, "TRANSFORMASI PONDOK PESANTREN MUADALAH:ANTARA FAKTA HISTORIS DAN TANTANGAN MASA DEPAN," Reflektika, vol.13, no. 1 (10 Juni 2019), 24-25.
} 
menunjukkan eksistensi dan pengembangnnya dalam menghadapi problematika.

Modernisasi telah merambah ke berbagai bidang. Salastunya pendidikan, termasuk pesantren. Modernisasi yang dilakukan dunia pesantren memiliki karakteristik tersendiri bila dibandingkan dengan pembaharuan di bidang lain. Keunikan pesantren terletak pada kealotan dan proses tarik menarik antara sifat dasar yang tradisional dengan potensi dasar modernisasi yang progresif dan senantiasa berubah. ${ }^{2}$

Pengelolaan sumber daya manusia dalam menjalankan manajemen sangatlah penting. Begitu juga di pesantren. Hal ini dikarenakan manajemen sumber daya manusia di pesantren sebagai lembaga atau organisasi erat kaitannya dengan pemberdayaan tenaga pendidik dan kependidikan, sejak masuk ke dalam organisasi pendidikan sampai akhirnya berhenti. Kegiatan ini mencakup proses perencanaan sumber daya manusia, perekrutan, seleksi, penempatan, pemberian kompensasi, penghargaan, pendidikan dan latihan pengembangan dan pemberhentian. ${ }^{3}$

Dalam pasal 6 pada Undang-undang No. 14 tahun 2005 tentang Guru dan Dosen disebutkan bahwa kedudukan guru dan dosen sebagai tenaga profesional bertujuan untuk melaksanakan sistem pendidikan nasional dan mewujudkan tujuan pendidikan nasional, yaitu berkembangnya potensi peserta didik agar

\footnotetext{
2 Basori Ruchman, The Founding Father Pesantren Modern Indonesia (Jakarta: Inchies, 2006), 33.

${ }^{3}$ Jaja Jahari dan Amirulloh Syarbini, Manajemen Madrasah: Teori, Strategi, dan Implementasi (Bandung: Al-Fabeta, 2013), 3.
} 
menjadi manusia yang beriman dan bertaqwa kepada Tuhan Yang Maha Esa, berakhlak mulia, sehat, berilmu, cakap, kreatif, mandiri, serta menjadi warga negara yang demokratis dan bertanggung jawab. ${ }^{4}$

Penelitian yang dilakukan oleh Neni Humairoh Sa'adah menyebutkan bahwa untuk meningkatkan mutu pendidikan di lembaganya, Kepala Sekolah SMP Muhammadiyah 3 Depok memaksimal membuat standarisasi kerja yang diberlakukan bersama pihak yayasan Muhammadiyah, yang meliputi pembinaan rutin bisa dilakukan dengan breafing. Sedangkan indikator peningkatan mutu yang terlihat disekolah ini adalah terpenuhinya tenaga pengajar, kedisiplinan pendidik, kedisiplinan para siswa, saran dan fasilitas yang memadai, prestasi siswa yang diraih dalam berbagai perlombaan dan prestasi belajar di daerah istimewa Yogyakarta. Namun juga termasuk bagian peningkatan mutu output yang beberapa siswa yang diterima beberapa di sekolah-sekolah favorit di Yogyakarta. $^{5}$

Selain itu, derdasar penelitian Heni Ardila dapat disimpulkan bahwa pelaksanaan menajemen sumber daya manusia di Madrasah Aliyah Nurul Islam Seribandung Kecamatan Tanjung Batu Kabupaten Ogan Ilir Palembang dilaksanakan dengan cukup baik. Yakni dengan menerapkan model menajemen personalia yang meliputi tujuh komponen yaitu ; perencanaan,

\footnotetext{
${ }^{4}$ Ibid., 33.

5 Neni Humairoh Sa'adah, "Manajemen Personalia Dalam Meningkatkan Mutu Pendidikan (Studi Kasus SMP 3 Muhammadiyah Sleman Yogyakarta" (UIN Sunan Kalijaga Yogyakarta, 2017).
} 
rekrutment, pembinaan, penempatan, kompensasi, pemberhentian dan penilaian. Dari penelitian ini disampaikan komponen dilaksanakan dengan baik yaitu perencanaan, rekrutment, pembinaan dan pemberhentian. Sedangkan tiga lainnya belum berjalan secara maksimal. ${ }^{6}$

Dari sini dapat disimpulkan bahwa penerapan manajemen sumberdaya manusia secara maksimal berpotensi meningkatkan kualitas organisasi. Begitupula dengan pengelolaan lembaga pendidikan, termasuk pesantren, juga mengimplementasikan pengelolaan manajemen sumberdaya manusia yang baik untuk mendapatkan mutu yang baik baik pula.

Pondok Pesantren Kembang Kuning Lancar Larangan Pamekasan Jawa Timur merupakan lembaga pendidikan Islam yang berupaya beradaptasi dengan perkembangan zaman. Hal terlihat dari upaya menerapkan manajemen dan administrasi berstandar modern. Salah satunya, yang dilakukan oleh Pengasuh Pesantren ini, yang berupaya menerapkan manajemen sumberdaya manusia secara baik dan maksimal, yakni dengan cara merekrut guru-guru untuk menjadi tenaga pengajar dengan cara musyawarah Pengasuh dengan para Majlis Kiyai untuk mencari guru pengabdian dari pondok lain.

\footnotetext{
${ }^{6}$ Heni Ardila, "Pelaksanaan Menajemen Personalia Di Madrasah Aliyah Nurul Islam Seribandung Kecamatan Tanjung Batu Kabupaten Ogan Ilir" (UIN Raden Fatah Palembang, 2016).
} 


\section{METODE PENELITIAN}

Penelitian ini menggunakan pendekatan kualitatif lapangan, studi kasus. ${ }^{7}$ Dengan pengumpulan data melalui: wawancara, ${ }^{8}$ observasi, ${ }^{9}$ dan dokumentasi. ${ }^{10}$ Adapun tahapan yang ditempuh ada tiga tahapan, yaitu sebagai berikut: pertama tahap pra lapangan; yaitu terdiri dari menyusun rancangan penelitian, memilih lapangan penelitian, mengurus penelitian, menjajaki dan menilai keadaan lapangan, memiliki dan memanfaatkan informan, menyiapkan perlengkapan penelitian, mengantisipasi persoalan etika penelitian. Tahap kedua yaitu tahap Pekerjaan Lapangan; yang terdiri dari memahami penelitian dan persiapan diri, memasuki lapangan, berperan serta sambil mengumpulkan data.

Sedangkan yang terakhir yaitu tahap Analisis Data; meliputi kegiatan organisasi dan kategorisasi data, menemukan tema dan merumuskan hipotesis, serta menganalisis atau mendeskripsikan data berdasarkan hipotesis.

\section{HASIL DAN PEMBAHASAN}

\section{Pengelolaan Manajemen Sumberdaya Manusia di Pesantren}

Pondok Pesantren Kembang Kuning Lancar Larangan Pamekasan Jawa Timur merupakan pondok pesantren pondok yang

\footnotetext{
7 Lexy J. Moleong, Metodologi Penelitian Kualitatif (Bandung: PT. Remaja Rosdakarya, 2011), 155.

${ }^{8}$ Mohammad Nazir, Metode Penelitian (Jakarta: Galia Indonesia, 2006), 193-194.

9 Sumadi Suryabrata, Metodelogi Penelitian Kualitatif (Jakarta: Rajawali Perss, 1991), 94.

${ }^{10}$ Cholid Narbuko dan Abu Ahmadi, Metodologi Penelitian (Jakarta: Bumi Aksara, 2001), 70.
} 
membawahi beberapa satuan pendidikan seperti MI, MTs dan MA. Dalam pengelolaan pendidikan di Pondok Pesantren Kembang Kuning ini memiliki berbagai macam solusi untuk membentuk pendidikan bermutu.

Pesantren ini menjalankan suatu manajemen, satuan manajemen yang ditempuh yaitu Manajemen sumber daya manusia. Manajemen sumber daya manusia ini dijalankan sejak tahun 2014 yang lalu, dan sampai sekarang masih tetap dipertahankan dan dikembangkan.

Adapun yang terlibat dalam pelaksanaan manajemen dari pihak pondok yang meliputi Kiyai sebagai Pemimpin Pondok, Ketua Yayasan, Sekretaris Pondok, dan sejumlah dewan guru yang berada di pondok ini. ${ }^{11}$ Pelibatan semua unsur di Pesantren dalam pengelolaan manajemen diharapkan agar semua siklus manajemen bisa dilakukan secara maksimal.

Dalam perencanaa misalnya, ada pembagian tugas ditentukan pada saat pelaksanaan perencanaan, dan hasilnya yaitu pemimpin pondok memberikan pengarahan dan pantauan dan memberi keputusan dari beberapa hal menjadi pertimbangan. ${ }^{12}$ Dalam manajemen perencanaan merupakan sebuah patokan untuk mempermudah manajer agar tercapainya sebuah tujuan, membuat strategi untuk mencapai tujuan itu, dan mengembangkan rencana aktivitas kerja organisasi. ${ }^{13}$

\footnotetext{
${ }^{11} \mathrm{KH}$. Amin Ja'far, "Peningkatan Mutu Pesantren melalui Manajemen SDM," 10 Maret 2017.

12 Ibid.

13 Frédéric Delmar dan Scott Shane, "Does Business Planning Facilitate the Development of New Ventures?," Strategic Management Journal, vol.24, no. 12 (2003), 1165-1185.
} 
Dalam praktiknya, Ketua Yayasan memberi sumbangan pertimbangan yang baik terhadap apa yang akan dilaksanakan. Sedangkan Sekretaris bertugas merangkum apa saja yang akan dilaksanakan dan melakukan pembukuan pertanggungjawaban dari apa yang akan dan yang telah dijalankan. Adapun dewan guru sebagai pembantu dari apa yang akan dilaksanakan. ${ }^{14} \mathrm{Hal}$ ini penting, karenan rencana adalah dokumen yang digunakan untuk mencapai tujuan. Rencana biasanya mencakup alokasi sumber daya, jadwal, dan tindakan-tidakan penting lainnya. ${ }^{15}$

Adapun tujuan dari pelaksanaan manajemen sumber daya manusia di pesantren ini ialah untuk dapat menciptakan kondisi yang mana tiap-tiap pengurus bahkan dari dewan guru dapat memberikan sumbangan sebaik mungkin untuk atasannya, dikarenakan tidak bisa mengharapkan efisiensi yang maksimal tanpa adanya kerjasama yang penuh dari para pengurus. ${ }^{16}$

Pengelolaan manajemen sumberdaya di Pesantren ini diharapkan dapat memperbaiki pemanfaatan sumber daya manusia, bisa menyesuaikan aktifitas sumber daya manusia, mampu meningkatkan efektivitas dan efisiensi pendayagunaan SDM, mampu meningkatkan efisiensi dalam menarik guru tugas baru. Dan dapat melengkapi informasi sumber daya manusia yang dapat membantu kegiatan sumber daya manusia dan unit organisasi lain. ${ }^{17}$

\footnotetext{
${ }^{14}$ Ja'far, "Peningkatan Mutu Pesantren melalui Manajemen SDM."

${ }^{15}$ Delmar dan Shane, "Does Business Planning Facilitate the Development of New Ventures?," 1165-1185.

${ }^{16} \mathrm{Ja}$ far, "Peningkatan Mutu Pesantren melalui Manajemen SDM."

${ }^{17}$ H. Moch. Holis, "Peningkatan Mutu Pesantren melalui Manajemen SDM," 11

Maret 2017.
} 
Undang-undang No. 14 tahun 2005 tentang guru dan dosen mengamanatkan bahwa guru sebagai agen pembelajaran guru harus berfungsi untuk meningkatkan mutu pendidikan nasional, pengembang ilmu pengetahuan, teknologi, dan seni, serta pengabdi kepada masyarakat. Dalam pasal 6 disebutkan bahwa kedudukan guru dan dosen sebagai tenaga profesional bertujuan untuk melaksanakan sistem pendidikan nasional dan mewujudkan tujuan pendidikan nasional, yaitu berkembangnya potensi peserta didik agar menjadi manusia yang beriman dan bertaqwa kepada Tuhan Yang Maha Esa, berakhlak mulia, sehat, berilmu, cakap, kreatif, mandiri, serta menjadi warga negara yang demokratis dan bertanggung jawab. ${ }^{18}$ Selain itu, kemampuan sumber daya manusia (SDM) dalam suatu organisasi sangat penting arti dan keberadaannya bagi peningkatan produktivitas kerja lingkungan organisasi tersebut. ${ }^{19}$

Peningkatan Mutu melalui Pengelolaan Manajemen Sumberdaya Manusia di Pesantren

Manajemen sumber daya manusia dan sumber daya manusia adalah "pengakuan" terhadap pentingnya satuan tenaga kerja organisasi sebagai sumber daya manusia yang vital bagi pencapaian tujuan organisasi, dan pemanfaatan berbagai fungsi dan kegiatan personalia untuk menjamin bahwa mereka

\footnotetext{
${ }^{18}$ Jahari dan Syarbini, Manajemen Madrasah: Teori, Strategi, dan Implementasi, 33.

${ }^{19}$ Ibid., 47.
} 
digunakan secara efektif dan bijak agar bermanfaat bagi individu, organisasi dan masyarakat. ${ }^{20}$

Pengakuan Pimpinan Pondok Pesantren Kembang Kuning Lancar Larangan Pamekasan Jawa Timur terhadap stafnya dapat dilihat dengan pemberian kesempatan kepada bawahannya dalam ikut serta dalam perencanaan. Salah satunya Sekretaris Pondok yang dianggap lebih profesional dalam hal pelaksaan sistem manajemen, dan juga tentang sistem manajemen sumber daya manusia. ${ }^{21}$ Pelibatan staf dalam perencanaan sangatlah penting. karena perencanaan (human resources planning) adalah merencanakan tenaga kerja secara efektif serta efisien agar sesuai dengan kebutuhan perusahaan dalam membantu terwujudnya tujuan. Perencanaan dilakukan dengan menetapkan program kepegawaian. Program kepegawaian meliputi pengorganisasian, pengarahan, pengendalian, pengadaan, pengembangan, kompensasi, pengintegrasian, pemeliharaan, kedisiplinan, dan pemberhentian, karyawan. Program kepegawaian yang baik akan membantu tercapainya tujuan perusahaan, karyawan dan masyarakat. ${ }^{22}$

Dalam menjalankan manajemen sumberdaya manusia, langkah pertama pertama yang dilakukan oleh pesantren ini ialah mengumpulkan sejumlah dewan guru dalam merancang suatu tujuan dan merencanakan apa saja yang akan ditempuh dan aturan apa saja yang akan diberlakukan. Sehingga dengan

\footnotetext{
${ }^{20}$ S.P. Malayu Hasibuan, Manajemen Dasar, Pengertian, dan Masalah (Jakarta: Bumi Aksara, 2007), 3-5.

${ }^{21}$ Ja'far, "Peningkatan Mutu Pesantren melalui Manajemen SDM."

22 Hasibuan, Manajemen Dasar, Pengertian, dan Masalah, 21.
} 
begitu pelaksanaan program ini akan berjalan sesuai dengan apa yang telah diharapkan bersama ${ }^{23}$

Selain itu yang tak kalah penting adalah pengorganisasian, dimana dapat dipahami bahwa pengorganisasian adalah kegiatan untuk mengorganisasi semua karyawan dengan menetapkan pembagian kerja, hubungan kerja, delegasi wewenang, integrasi, dan koordinasi dalam bagan organisasi (organization chart). Organisasi hanya merupakan alat untuk mencapai tujuan. Dengan organisasi yang baik akan membantu terwujudnya tujuan secara efektif. ${ }^{24}$ Pimpinan Pondok Pesantren Kembang Kuning sangat menyadari akan hal ini, dibuktikan dengan dukungan dari pihak Yayasan yang juga memiliki komitmen kuat dalam peningkatan mutu dan kualitas pesantren ini dengan melakukan beberapa tahapan-tahapan pengembangan sumber daya manusianya, antara lain: proses penyusunan personalia, perencanaan penetapan personalia, pelaksanaan tugas-tugas, pemberian pelatihan dan pengembangan dan pemberian kompensasi dan sanksi. ${ }^{25}$

Selanjutnya dalam hal pengarahan. Pesantren ini sangat intensif dalam pemberian pengarahan kepada guru dan tenaga kependidikan yang menjadi binaannya. Sistem pengarahan yang dilakukan yaitu dengan mengadakan forum atau pertemuan internal yang di dalamnya berkaitan dengan sistem pengelolaan manajemen. ${ }^{26} \mathrm{Hal}$ ini dilakukan karena Pimpinan Pondok sadar

\footnotetext{
${ }^{23}$ Ja'far, "Peningkatan Mutu Pesantren melalui Manajemen SDM."

${ }^{24}$ Hasibuan, Manajemen Dasar, Pengertian, dan Masalah, 21.

${ }^{25}$ Holis, "Peningkatan Mutu Pesantren melalui Manajemen SDM."

${ }^{26}$ Ja'far, "Peningkatan Mutu Pesantren melalui Manajemen SDM."
} 
bahwa untuk memaksimalkan kegiatan staf perlu ada pengarahan. Karena pengarahan (directing) adalah kegiatan mengarahkan semua karyawan agar mau bekerja sama dan bekerja efektif serta efisien dalam membantu tercapainya tujuan perusahaan, karyawan dan masyarakat. Pengarahan dilakukan pimpinan dengan menugaskan bawahan agar mengerjakan semua tugasnya dengan baik. ${ }^{27}$

Langkah yang tak kalah penting dan perlu dilakukan adalah pengendalian (controlling) yakni kegiatan mengendalikan semua karyawan, agar mentaati peraturan-peraturan perusahaan dan bekerja sesuai dengan rencana. Apabila terdapat penyimpangan atau kesalahan, diadakan tindakan perbaikan dan penyempurnaan rencana. Pengendalian karyawan meliputi kehadiran, kedisiplinan, prilaku, kerja sama, pelaksanaan pekerjaan, dan menjaga situasi lingkungan pekerjaan. ${ }^{28}$ Dalam melakukan pengendalian sumber daya manusianya, pesantren ini menugaskan Ketua Yayasan untuk membantu pemimpin pondok dalam mengawasi beberapa pelaksanaan manajemen ini, selain itu juga harus memberikan pengarahan yang baik bagi semua pihak. $^{29}$

Selain pengendalian perlu ada pengawasan yakni kegiatan mengamati (observasi) dan juga membandingkan pelaksanaan dengan terencana dan juga mengoreksinya jika terjadi suatu penyimpangan dengan arti lain pengawasan adalah suatu fungsi yang menyangkut suatu masalah pengaturan berbagai jenis

\footnotetext{
${ }^{27}$ Hasibuan, Manajemen Dasar, Pengertian, dan Masalah, 22.

${ }^{28}$ Ibid., 23.

${ }^{29}$ Holis, "Peningkatan Mutu Pesantren melalui Manajemen SDM."
} 
kegiatan atau aktivitas sesuai dengan rencana personalia yang sudah dirumuskan sebagai dasar analisis dari tujuan organisasi fundamental. ${ }^{30}$ Dalam proses ini pesantren memanfaatkan keberadaan Ketua Yayasan ${ }^{31}$ dan kegiatan pengarahan rutin oleh Pimpinan Pondok menjadi media komunikasi antara pihak pimpinan dan staf di pesantren sini. ${ }^{32}$

\section{SIMPULAN}

Sistem manajemen sumber daya manusia merupakan suatu komponen yang dihubungkan dalam memudahkan aliran informasi antar satu dengan yang lainnya, model manajemen yang dilakukan di Pondok Pesantren Kembang Kuning Lancar yaitu dengan beberapa komponen, diantaranya yaitu perencanaan, pengorganisasian, pengarahan dan pengendalian. Dalam perkembangannya, Pondok pesantren perlu melakukan kompromi dengan modernisasi manajemen dan tata kelolanya.

Akan tetapi keberadaan pesantren sebagai satu-satunya lembaga pendidikan Islam asli yang dimiliki oleh Indonesia patut dilestarikan dan mendapat apresiasi dari pemerintah guna menjaga eksistensinya. Selain itu perlu ada keterbukaan dari pihak Kiyai sebagai top figur dan leader di lembaga yang berbasis keislaman ini dalam menyikapi perkembangan zaman.

\footnotetext{
${ }^{30}$ Hasibuan, Manajemen Dasar, Pengertian, dan Masalah, 23.

${ }^{31}$ Holis, "Peningkatan Mutu Pesantren melalui Manajemen SDM."

32 Ja'far, "Peningkatan Mutu Pesantren melalui Manajemen SDM."
} 


\section{REFERENSI}

Ardila, Heni. "Pelaksanaan Menajemen Personalia Di Madrasah Aliyah Nurul Islam Seribandung Kecamatan Tanjung Batu Kabupaten Ogan Ilir." UIN Raden Fatah Palembang, 2016.

Delmar, Frédéric, dan Scott Shane. "Does Business Planning Facilitate the Development of New Ventures?" Strategic Management Journal, vol.24, no. 12 (2003): 1165-1185.

Hamzah, Moh. "Transformasi Pondok Pesantren Muadalah antara Fakta Historis dan Tantangan Masa Depan." Reflektika, vol.13, no. 1 (10 Juni 2019): 23-48.

Hasibuan, S.P. Malayu. Manajemen Dasar, Pengertian, dan Masalah. Jakarta: Bumi Aksara, 2007.

Holis, H. Moch. "Peningkatan Mutu Pesantren melalui Manajemen SDM," 11 Maret 2017.

Ja'far, KH. Amin. "Peningkatan Mutu Pesantren melalui Manajemen SDM," 10 Maret 2017.

Jahari, Jaja, dan Amirulloh Syarbini. Manajemen Madrasah: Teori, Strategi, dan Implementasi. Bandung: Al-Fabeta, 2013.

Moleong, Lexy J. Metodologi Penelitian Kualitatif. Bandung: PT. Remaja Rosdakarya, 2011.

Narbuko, Cholid, dan Abu Ahmadi. Metodologi Penelitian. Jakarta: Bumi Aksara, 2001.

Nazir, Mohammad. Metode Penelitian. Jakarta: Galia Indonesia, 2006.

Ruchman, Basori. The Founding Father Pesantren Modern Indonesia. Jakarta: Inchies, 2006.

Sa'adah, Neni Humairoh. "Manajemen Personalia Dalam Meningkatkan Mutu Pendidikan (Studi Kasus SMP 3 Muhammadiyah Sleman Yogyakarta." UIN Sunan Kalijaga Yogyakarta, 2017.

Suryabrata, Sumadi. Metodelogi Penelitian Kualitatif. Jakarta: Rajawali Perss, 1991. 
Mashuri Toha, Parisi | MAHAROT Vol. 4, No. 1, 2020 